\title{
PELANGGARAN HAK ASASI MANUSIA DALAM KEBIJAKAN DAERAH DI BIDANG TATA RUANG DI KABUPATEN KUNINGAN
}

\author{
Haris Budiman \\ Fakultas Hukum Universitas Kuningan \\ Email:budiman9@yahoo.co.id
}

\begin{abstract}
Human rights are rights that exist and attach to the human self or dignity, because he is human. The formulation of the problem How the Human Rights Arrangements in Spatial Planning in Indonesia and How Regional Policies in Spatial Planning in Protecting Human Rights of the Community of Kuningan Regency. The purpose of this study is to How the Human Rights Arrangements in Spatial Planning in Indonesia and How Regional Policies in Spatial Planning in Protecting Human Rights of the Community of Kuningan Regency. The research method used by the researcher is using the normative juridical approach. The results of the Indonesian Human Rights Arrangements have been regulated in the 1945 Constitution and listed in Article $28 \mathrm{~A}$ through $28 \mathrm{~J}$ and the Regional Policy in the field of spatial planning has occurred inconsistency that there has been conversion of agricultural land into housing especially in South Cilimus, Whose tataruang direction is for the development of the agricultural sector and support for the development of tourism, occurs due to the lack of awareness of the public in protecting the environment, the low awareness of the law of the apparatus of policy organizers, and the efforts of local governments to keep increasing the PAD regardless of the spatial plan that has been established, Various violations of the conversion of agricultural land into residential buildings. Conclusion The regulation on human rights has been very clear in the Constitution and the Law applicable in Indonesia. Implementation of human rights in all aspects of life, especially the Spatial need support from all parties, especially the government itself must be consistent in carrying out all the regulations and the need to increase the capacity of the civil apparatus of the state so that in running the government always obedient and obedient to the rules of law, especially spatial.
\end{abstract}

Keywords: Human Rights Spatial Planning Policy.

\section{Abstrak}

Hak Asasi Manusia adalah hak yang ada dan melekat pada diri atau martabat manusia, karena dia adalah manusia. Adapun rumusan masalah Bagaimana Pengaturan Hak Asasi Manusia dalam Bidang Tata Ruang di Indonesia dan Bagaimana Kebijakan Daerah di Bidang Tata Ruang dalam Melindungi Hak Asasi Masusia Masyarakat Kabupaten Kuningan. Adapun tujuan penelitian ini adalah untuk Bagaimana Pengaturan Hak Asasi Manusia dalam Bidang Tata Ruang di Indonesia dan Bagaimana Kebijakan Daerah di Bidang Tata Ruang dalam Melindungi Hak Asasi Masusia Masyarakat Kabupaten Kuningan. Metode penelitian yang digunakan oleh peneliti adalah menggunakan pendekatan yuridis normatif. Hasil penelitian Pengaturan Hak Asasi Manusia di Indonesia, sudah diatur dalam Undang Undang Dasar 1945 dan tercantum pada Pasal 28 A s/d $28 \mathrm{~J}$ dan Kebijakan Daerah di bidang penataanruang telah terjadi inkonsistensi yaitu telah terjadi alih fungsi lahan pertanian menjadi perumahan terutama di kawasan Cilimus Selatan, yang arahan tataruangnya adalah untuk pengembangan sector pertanian dan dukungan terhadap pengembangan pariwisata, terjadi karena minimnya kesadaran masyarakat dalam menjaga lingkungan, rendahnya kesadaran hukum aparatur penyelenggara kebijakan, dan upaya pemerintah daerah untuk terus meningkatakan PAD tanpa melihat rencana tata ruang yang telah ditetapkan, telah menimbulkan berbagai pelanggaran alih fungsi lahan pertanian menjadi bangunan perumahan. Kesimpulan Pengaturan tentang HAM sudah sangat jelas dalam Konstitusi dan Undang-Undang yang berlaku di Indonesia. Penerapan HAM di dalam semua aspek kehidupan khususnya Tata Ruang perlu dukungan dari semua pihak terutama pemerintah sendiri yang harus konsisten dalam menjalankan semua peraturan dan perlu 
adanya peningkatan kapasitas aparatur sipil negara sehingga dalam menjalankan roda pemerintahaan senantiasa patuh dan taat terhadap peraturan perundangan khususnya mengaenai tata ruang.

Kata kunci : Hak Asasi Manusia Kebijakan Penataan Ruang.

\section{PENDAHULUAN}

Hak Asasi Manusia adalah hak yang ada dan melekat pada diri atau martabat manusia, karena dia adalah manusia. Hak itu ada dalam diri manusia, dan tidak dapat dipisahkan darinya. Hak itu dimiliki oleh manusia, karena dia itu makhluk yang namanya manusia. Hak itu bukannya diperolehnya atau dianugerahkannya dari suatu otoritas negara atau pemerintahan, tetapi dimiliki manusia karena dia itu bermartabat manusiawi. Justru karena sebagai manusia maka manusia itu memiliki Hak-Hak yang Asasi, hak yang fundamental, yang tidak dapat dipisahkan atau diceraikan dari dirinya sendiri. Kalau haknya itu dipisahkan dari sang manusia itu, maka nilai kemanusiaannya atau martabatnya itu akan merosot, direndahkan, dihina dan dirong-rong. Dan dia tidak dihargai sebagai manusia lagi.

Dalam Undang-Undang No. 39 tahun 1999 mengenai Hak-Hak Asasi manusia dirumuskan: "hak asasi manusia merupakan hak dasar yang secara kodrati melekat pada diri manusia, bersifat universal dan langgeng, oleh karena itu harus dilindungi, dihomati, dipertahankan, dan tidak boleh diabaikan, dikurangi, atau dirampas oleh siapapun", dan "Hak asasi manusia adalah seperangkat hak yang melekat pada hakikatnya dan keberadaan manusia sebagai makhluk Tuhan Yang Maha Esa dan merupakan anugerah-nya yang wajib dihormati, dijunjung tinggi dan dilindungi oleh negara, hukum, Pemerintah, dan setiap orang demi kehormatan serta perlindungan harkat dan martabat manusia" .

Pengendalian pemanfaatan ruang di Kabupaten Kuningan tertuang dalam Peraturan Daerah Kabupaten Kuningan Nomor 26 Tahun 2011 tentang Rencana Tata Ruang Wilayah Kabupaten Kuningan Tahun 2011-2031. Rencana tata ruang ini sebagai pedoman dalam menetapkan Rencana Pembangunan Jangka Panjang (RPJP) dan Rencana Pembangunan Jangka Menengah (RPJM) Kabupaten Kuningan. Tujuan utamanya adalah untuk mendukung
Kabupaten Kuningan sebagai Kabupaten Konservasi berbasis Pertanian dan Pariwisata yang berdaya saing. Oleh karena itu rencana struktur ruang wilayah di Kabupaten Kuningan telah diatur dalam Pasal 7 ayat (1) Peraturan Daerah tersebut yang meliputi Sistem Pusat Kegiatan dan Sistem Jaringan Prasarana Wilayah. Sistem Pusat Kegiatan terdiri atas Sistem Perkotaan dan Sistem Perdesaan. Sistem Perkotaan Kabupaten terdiri atas Pusat Kegiatan Lokal dan Pusat Pelayanan Kawasan. Pusat Kegiatan Lokal adalah kawasan perkotaan yang berfungsi untuk melayani kegiatan skala kabupaten atau beberapa kecamatan. Sedangkan Pusat Pelayanan Kawasan adalah kawasan perkotaan yang berfungsi untuk melayani kegiatan skala kecamatan atau beberapa desa. Pusat Kegiatan Lokal di Kabupaten Kuningan meliputi lima Kecamatan yaitu Kecamatan Kuningan, Kecamatan Cilimus, Kecamatan Ciawigebang, Kecamatan Luragung dan Kecamatan Kadugede. Penentuan kelima kecamatan tersebut sebagai Pusat Kegiatan Lokal karena memiliki karakteristik dan keunggulan yang berbeda-beda. Perbedaantersebuttertuangdalam pasal 10 ayat (2) Peraturan Daerah Tata Ruang.

Pedoman bahwa pengelolaan tata ruang sebagai acuan pembangunan, sering dikesampingkan dan dipaksakan ketika terdapat keinginan untuk melaksanakan pembangunan dengan orientasi meningkatkan Pendapatan Asli Daerah, yang sebenarnya tidak sesuai dengan rencana tata ruang yang berlaku. Seperti halnya kondisi tersebut di atas minat investasi dalam rangka mendorong meningkatkan laju pertumbuhan ekonomi dan pendapatan daerah seringkali dipandang sebagai dasar untuk merubah atau merevisi rencana tata ruang yang disesuaikan sebagai alat pembenar bagi kegiatan investasi. Menurut Esmi Warassih, apabila pembangunan itu merupakan suatu kegiatan untuk melakukan perubahan dalam masyarakat, maka dapat dipahami bahwa 
peranan pemerintah sebagai lembaga eksekutif menjadi semakin menonjol. Melalui peraturan hukum, pemerintah dapat melaksanakan kebijakan pembangunan, harus diingat bahwa persoalan yang dihadapi pada saat ini bukan sekedar masalah legalitas formal, melainkan tuntutan keadaan yang saat ini menghendaki agar hukum dilihat dalam kerangka yang lebih luas yang sedang berkembang dalam masyarakat. ${ }^{1}$

Realitas ini jelas sangat bertentangan dengan tujuan yang dikehendaki oleh norma Peraturan Daerah Nomor 26 Tahun 2011 tentang Rencana Tata Ruang Wilayah Kabupaten Kuningan. Alasan pokok yang mengakibatkan terjadinya kondisi seperti tersebut diatas diakibatkan oleh proses bekerjanya hukum yang dipengaruhi oleh faktor-faktor metayuridis (non hukum) yaitu faktor kekuatan ekonomi yang dapat mempengaruhi pelaksanaan Peraturan Daerah Nomor 26 tahun 2011. Dengan demikian maka kebijakan tersebut telah mengorbankan kepentingan dari hak masyarakat di Kabupaten Kuningan karena Pemerintah daerah tidak melindungi dan mensejahterakan warganya yang merupakan hak pokok yang harus dimiliki oleh setiap manusia.

\section{RUMUSAN MASALAH}

Berkaitan dengan latar belakang yang telah diuraikan di atas, maka rumusan masalah dalam tulisan ini dirumuskan sebagai berikut:

1. Bagaimana Pengaturan Hak Asasi Manusia dalam Bidang Tata Ruang di Indonesia?

2. Bagaimana Kebijakan Daerah di Bidang Tata Ruang dalam Melindungi Hak Asasi Masusia Masyarakat Kabupaten Kuningan?

\section{METODE}

Penelitian yang digunakan oleh penulis adalah yuridis empiris. Data yang digunakan dalam penelitian ini adalah data primer yaitu wawancara dan data sekunder yaitu bahan hukum primer mulai dari UUD 1945, Undang-

\footnotetext{
${ }^{1}$ Esmi Warassih, Pranata Hukum Sebuah Telaah Sosiologis,(Badan Penerbit Universitas Diponegoro, Semarang, 2011) hlm 111-112
}

Undang Nomor 26 Tahun 2007 tentang Penataan Ruang, bahan hukum sekunder berupa jurnal, penelitian-penelitain terdahulu serta buu referensi yang relevan. Metode penelitian hukum, menurut Soerjono Soekanto adalah " suatu kegiatan ilmiah, yang di dasarkan pada metode, sistematika dan pemikiran tertentu, yang bertujuan mempelajari satu atau beberapa gejala hukum tertentu, dengan menganalisanya .

\section{PEMBAHASAN}

\section{Pengaturan Hak Asasi Manusia dalam} Bidang Tata Ruang di Indonesia.

Hak asasi manusia menjadi pembahasan penting setelah Perang Dunia II dan pada waktu pembentukan Perserikatan Bangsa-Bangsa tahun 1945. Istilah HAM mengantikan istilah Natural Rights. Hal ini karena konsep hukum alam yang berkaitan dengan hak-hak alam menjadi suatu konroversial. Hak asasi manusia yang dipahami sebagainatural rightsmerupakan suatu kebutuhan dari realitas sosial yang bersifat universal. Semula HAM berada di negara-negara maju. Sesuai dengan perkembanagan kemajuan transportasi dan komunikasi secara meluas, maka negara berkembang sepreti Indonesia, mau tidak mau sebagi anggota PBB, harus menerimanya untuk melakukan ratifiksi istrumen HAM internasional sesuai dengan falsafah Pancasila dan Undang-Undang Dasar 1945, serta kebudayaan bangsa Indonesia.

Perkembangan HAM di Indonesia, sebenarnya dalam UUD 1945 telah tersurut, namun belum terancam secara transparan. Setelah dilakukan Amandemen I s/d IV Undang-Undang Dasar 1945, ketentuan tentang HAM tercantum pada Pasal 28 A s/d $28 \mathrm{~J}$. Sebenaranya pada UUDS 1950 yang pernah berlaku dari tahun 1949-1950, telah memuat pasal-pasal tentang HAM yang lebih banyak dan lengkap dibandingkan UUD 1945. Namun Konstituante yang terbentuk mulai pemilihan umum tahun 1955 dibubarkan berdasarkan Keppres Nomor 150 tahun 1959, tanggal 5 Juli 1959. Secara otomatis hal ini mengakibatkan kita kembali lagi pada UUD 1945.

Pemunculan, perumusan dan institusionalisai Hak Asasi Manusia HAM) memang tak dapat 
dilepaskan dari lingkungan sosial atau habitatnya, yaitu tidak lain masyarakat itu sendiri di mana HAM itu dikembangkan. Terjadi semacam korespondensi antara HAM dan perkembangan masyarakat. Kita juga dapat mengatakan, bahwa HAM itu memiliki watak sosial dan struktur sosial sendiri. "institusi dalam masyarakat berkorespondensi dan berkelindang dengan lingkungan sosialnya". Oleh karena itu kehadiran suatu institusi ingin dijelaskan dari konteks sosial dan historisnya.

Kita coba melacak HAM dari segi perkembangan historisnya dan meneliti dalam konteks sosial yanga bagaimana ia muncul. Dokumen-dokumen paling awal yang memasuki HAM adalah Bill of Rights (Inggris, 1688), Declaration of the Rights of Man and of the Citizen (Prancis, 1789), dan Bill of Rights (Amerika, 1791). Benar, seperti dikatakan oleh Behr, bahwa HAM itu berasal dari rumusan di Barat. Dokumen-dokumen tersebut mewakili pikiran yang ada di belakangnya yang mendorong dokumen tersebut. Dengan demikian dokumen tersebut kita baca sebagai isyarat (sign) adanya atau kelahiran gagasan yang ada di belakangnya.

Kemudian sejak kemunculannya sampai hari ini HAM telah mengalami perkembangan dan perubahan yang dikenal dengan sebutan generasi HAM. Generasi pertama meliputi hakhak sipil dan politik. Generasi kedua meliputi hak-hak sosil, ekonomi dan budaya. Akhirnya generasi ketiga memuat sejumlah hak-hak kolektif, seperti: hak ats perkembangan/ kemajuan (development); hak atas kedamaian, hak atas lingkungan yang bersih hak atas kekayaan alam dan hak ats warisan budaya. Kita sudah berbicara panjang lebar tentang mainstream HAM di dunia. Tetapi dunia tidak sama dengan Eropa atau Barat, melainkan jauh lebih luas dan besar dari pada itu. Yang dikatakan disinia adalah, bahwa masyarakat dan bangsa-bangsa di dunia ada beraneka ragam. Beraneka ragam dalam habitat fisiknya, tradisi kultural, nilai-nilainya, kosmologinya serta pandangannya tentang manusia dan dunia.

Selanjutnya perkembangan yang sehat dari usaha pemajuan HAM adalah melalui 'pengakuan terhadap kemajemukan di dunia ini. Tanpa mengakui kemajemukan tersebut, maka alih-alih memajukan HAM dunia malah akan terjebak ke dalam suasana konflik yang bisa memuncak pada pelanggaran HAM sendiri, terutama sejak HAM sudah memasuki generasi ketiga, yang antara lain memuat hak atas warisan budaya. Dalam model pemjuan HAM yang demikian itu tidak ada tempat bagi pemaksaan dan dominasi dari satu konsep HAM tertentu di atas yang lain. Apalagi sejak munculnya aliran pemikiran yang kontra-rasional dan kontra-individual di dunia sebagaimana diuraikan dimuka. Yang ada adalah suasana saling penghormatan dan saling memberi tahun serta saling memperkaya satu sama lain. Konferensi-konferensi HAM Internasional hanya akan menjadi medan pertukaran pengalaman dan forum pembelajaran, bukan menjadi tempat untuk menggiring bangsa dan negara di dunia ini kearah pemahaman HAM secara seragam menurut satu standar mutlak

Pada masa pemerintahan orde baru, demokrasi belum berjalan baik. Terlihat misalnya seperti kebebasan mengemukakan pendapat di muka umum, kebebasan pers maupun kebebasan dalam organisasi dan sebagainya. Hanya kepentingan-kepentingan politik yang menonjol pada saat itu, sehingga gerak-gerik masyarakat terbatas oleh ketentuan politik dan meliterisme. Demi nama baik bangsa dan masyarakat di Indonesia sebagai anggota PBB, maka untuk menghormati Piagam PBB, dan Deklarasi Universal HAM, serta untuk perlindungan, pemajuan, penegakkan, dan pemenuhan HAM sesuai dengan prinsip-prinsip kebudayaan bangsa Indonesiadan Pancasila.

Adapun karakteristik dari Hak-Hak Asasi Manusia adalah universal, berlaku umum di mana saja tetap sama, mutlak tidak dapat ditawartawar, tak terpisahkan dari hidup manusia, langgeng, kekal-abadi, tidak boleh dilecehkan oleh siapapun. Hak-Hak Asasi Manusia itu sungguh-sunggu merupakan hak yang dasar, fundamental dalam kehidupan manusia itu sendiri. HAM di dalam Islam salah satunya diabadikan di dalam Al-Qur'an dan tradisi 
kenabian. Rasulluallah Muhammad SAW bersabda: "Hidupmu, milikmu, dan martabatmu sesuci hari ini (sewaktu naik haji)."

2. Kebijakan Daerah di Bidang Tata Ruang dalam Melindungi Hak Asasi Masusia Masyarakat Kabupaten Kuningan

Pengendalian pemanfaatan ruang di Kabupaten Kuningan tertuang dalam Peraturan Daerah Kabupaten Kuningan Nomor 26 Tahun 2011 tentang Rencana Tata Ruang Wilayah Kabupaten Kuningan Tahun 2011-2031. Rencana tata ruang ini sebagai pedoman dalam menetapkan Rencana Pembangunan Jangka Panjang (RPJP) dan Rencana Pembangunan Jangka Menengah (RPJM) Kabupaten Kuningan. Tujuan utamanya adalah untuk mendukung Kabupaten Kuningan sebagai Kabupaten Konservasi berbasis Pertanian dan Pariwisata yang berdaya saing. Oleh karena itu rencana struktur ruang wilayah di Kabupaten Kuningan telah diatur dalam Pasal 7 ayat (1) Peraturan Daerah tersebut yang meliputi Sistem Pusat Kegiatan dan Sistem Jaringan Prasarana Wilayah. Sistem Pusat Kegiatan terdiri atas Sistem Perkotaan dan Sistem Perdesaan. Sistem Perkotaan Kabupaten terdiri atas Pusat Kegiatan Lokal dan Pusat Pelayanan Kawasan. Pusat Kegiatan Lokal adalah kawasan perkotaan yang berfungsi untuk melayani kegiatan skala kabupaten atau beberapa kecamatan. Sedangkan Pusat Pelayanan Kawasan adalah kawasan perkotaan yang berfungsi untuk melayani kegiatan skala kecamatan atau beberapa desa. Pusat Kegiatan Lokal di Kabupaten Kuningan meliputi lima Kecamatan yaitu Kecamatan Kuningan, Kecamatan Cilimus, Kecamatan Ciawigebang, Kecamatan Luragung dan Kecamatan Kadugede. Penentuan kelima kecamatan tersebut sebagai Pusat Kegiatan Lokal karena memiliki karakteristik dan keunggulan yang berbeda-beda. Perbedaantersebuttertuangdalam pasal 10 ayat (2) Peraturan Daerah Tata Ruang.

Walaupun tidak secara jelas dibuat peraturan mengenai penetapan Kabupaten Kuningan sebagai Kabupaten Konservasi, akante tapi Pemerintah Daerah telah mengeluarkan norma-norma yang menguatkan Kabupaten
Kuningan sebagai Kabupaten Konservasi, diantaranya Peraturan Daerah Nomor 12 Tahun 2007 tentang Konservasi Sumber Daya Air, Peraturan Daerah Nomor 11 Tahun 2013 tentang Hutan Kota, serta berbagai berbagai peraturan daerah lainnya. Oleh karena itu menjadi suatu pertanyaan manakala pada tataran implementasi kebijakan yang dibangun oleh Pemerintah Daerah Kabupaten Kuningan memiliki kecenderungan yang cukup mendalam untuk terjadinya pelanggaran alih fungsi peruntukan. Misalnya penetapan Pusat Kegiatan Lokal di lima Kecamatan yang berbasis karakteristik wilayah pada penerapannya seringkali tidak sesuai dengan apa yang telah direncanakan. Seperti Pusat Kegiatan Lokal Kecamatan Cilimus yang seharusnya memiliki fungsi utama untuk kawasan pertanian dan pariwisata malah saat ini berkembang menjadi kawasan perumahan dan pemukiman baru.

Kondisi seperti ini menyebabkan Kabupaten Kuningan yang secara geografis terletak berada di kaki gunung Ciremai sekaligus sebagai penyuplai kebutuhan air di wilayah Cirebon, dalam tiga tahun terakhir sudah mengalami krisis air bersih. Data di DinasPertanianmenunjukan bahwa tahun 2009 Kabupaten Kuningan yang pada awalnya memiliki 620 titik mata air yang bersumber dari Gunung Ciremai, saat ini mengalami penurunan menjadi 523 titik mata air, dan kemungkinan besar titiktitik tersebut akan semakin terus berkurang. ${ }^{2}$ Begitu pula area pertanian, banyak lahan pertanian terutama sawah yang beralih fungsi, dalam tiga tahun terakhir lahan sawah di Kabupaten Kuningan menyusut seluas 262 ha atau dari semula 29.078 ha menjadi 28.816 ha. $^{3}$

Berdasarkan data di atas terlihat bahwa tujuan utama pengaturan tat aruang di Kabupaten Kuningan menurut Peraturan Daerah Nomor 26 Tahun 2011 adalah mendukung Kuningan sebagai Kabupaten Konservasi

\footnotetext{
2 Keterangan Kepala Bappeda Kabupaten Kuningan, sebagaimana dimuat dalam HU Radar Cirebon, 8 Pebruari 2015

3 Keterangan Kepala Dinas Pertanian dan Peternakan, sebagimana dimuat dalam HU Radar Cirebon, 10 Desember 2015.
} 
berbasis pertanian dan pariwisata . akan tetapi dalam tataran implementasi kebijakan tujuan tersebut tidak dijadikan pedoman oleh pejabat pemerintahan Kabupaten Kuningan. Pembentukan lima wilayah sebagai Pusat Kegiatan Lokal dalam rangka memepercepat pertumbuhan wilayah berbasis karakteristik kawasan pun tidak diterapkan dengan baik sesuai dengan ketentuan. Pusat-Pusat Kegiatan Lokal di Kabupaten Kuningan, yang focus utamanya untuk pengembangan wilayah berbasis karakteristik malah berkembang menjadi kawasan yang tidak sesuai dengan zonasi tata ruang seperti menjadi perumahan dan pemukiman baru. Data menunjukan sejak tahun 2011 ada 24 (dua puluh empat) perusahaan pengembang yang telah mendapatkan ijin untuk membangun kawasan perumahan di wilayah Kabupaten Kuningan, ${ }^{4}$

Hasil penelitian di wilayah studi, dapat dideskripsikan bahwa kebijakan yang dibuat oleh Pemerintah Daerah tidak berpedoman kepada Rencana Detail Tata Ruang (RDTR) Kecamatan Cilimus yang telah disusun. Ini menunjukan sebagaimana dikemukakan oleh Chamblis dan Seidman5 bahwa terdapat faktorfaktor atau kekuata-kekuatan yang bersifat personal dan sosial yang berupaya untuk mempengaruhi Pemerintah Daerah dalam membuat kebijakan dalam menerapkan rencana tata ruangnya. Faktanya telah terjadi pelanggaran alih fungsi peruntukan hampir di seluruh kawasan pengembangan terutama di kawasan perkotaan Cilimus bagian selatan. Dalam Rencana Detail Tata Ruang sebagaimana tersebut di atas, kawasan ini arahannya untuk pengembangan pendukung kegiatan pariwisata, agribisnis dan pengolahan hasil pertanian dan perkebunan. Sedangkan untuk pengembangan pemukiman cenderung ditutup atau sangat dibatasi karena adanya areal sawah beririgasi teknis. Akan tetapi data yang diperoleh dari

\footnotetext{
${ }^{4}$ Data Perumahan di KabupatenKuninganTahun 2011-2014, Dinas Tata RuangdanCiptaKarya

${ }^{5}$ EndangSutrisno,

KontruksiBudayaHukumMasyarakatNelayanUntukmembangu nKesejahteraanNelayan (Yogyakarta, Genta Publishing, 2013), hlm 114
}

Dinas Tata Ruang dan Cipta Karya Kabupaten Kuningan6 memperlihatkan kondisi yang berlainan. Saat ini dari 11 (sebelas) perusahaan pengembang yang sedang berinvestasi di Cilimus, ada 2 (dua) perusahaan pengembang besar karena beberapa kali mengajukan ijin pembangunan yang sedang melakukan pembangunan perumahan baru yang berlokasi di Desa Bandorasa Wetan (Kawasan Selatan) dengan luas tanah mencapai $110.000 \mathrm{~m} 2$.

Data di atas menunjukan bahwa ada inkonsisten dalam kebijakan di bidang tata ruang di Kabupaten Kuningan. Implikasinya tentu sangat luas tidak saja pada bidang ekonomi, tetapi juga pada bidang-bidang lainnya. Mengacu pada proses pembuatan kebijakan David Easton melalui Model Kotak Hitam Estonian $^{7}$ dapat dideskripsikan bahwa kebijakan sebagai suatu output dipengaruhi oleh input yang di dalamnya terdapat pihak-pihak yang terlibat dalam proses tersebut dan sangat bergantung pada sistem politik. Proses yang cukup panjang ini merupakan proses transformasi dari beberapa tuntutan ke dalam suatu keputusan yang otoritatif. ${ }^{8}$ Ketidakpatuhan pada suatu peraturan telah menyebabkan Kuningan banyak mengalami kehilangan lahan pertanian yang beririgasi sehingga dalam tiga tahun terakhir lahan sawah menyusut seluas 262 hektar atau dari semula 29.078 hektar menjadi 28.816 hektar. ${ }^{9}$

Peraturan Daerah Nomor 26 Tahun 2011 pada tataran pelaksanaannya tidak sesuai dengan semangat awal yaitu untuk mendukung Kabupaten Kuningan sebagai Kabupaten Konservasi dan sekaligus dapat meningkatkan kesejahteraan masyarakatnya melalui peningkatan pendapatan asli daerah. Adanya pengaruh atau kekuatan sosial dan personal sebagaimana dikemukakan oleh Chambliss dan Robert Seidman sangat jelas dalam

\footnotetext{
${ }^{6}$ Data Perumahan di KabupatenKuninganTahun 2011-2014, Dinas Tata RuangdanCiptaKaryaKabupatenKuningan

${ }^{7}$ EndangSutrisno, Op.cithlm 280

${ }^{8}$ EsmiWarassih, Op.Cit, hlm 44

${ }^{9}$ KeteranganKepalaDinasPertanianKabupatenKuningansebagai manatermuatdalamHarianUmum Radar Cirebon, tanggal 10 Desember 2014
} 
implementasi kebijakan tata ruang di Kabupaten Kuningan sebagaimana diatur dalam Peraturan Daerah tersebut. Pengaruh sosial berupa kontrol dari masyarakat terhadap kebijakan yang dirumuskan oleh Pemerintah Daerah dalam hal ini Bupati dan DPRD, pada akhirnya tidak terjadi karena kekuatan personal lebih dominan dibandingkan kekuatan sosial.

Dominasi kekuatan personal dalam penerapan kebijakan tata ruang dapat terlihat dari keinginan kuat Pimpinan Daerah (Bupati) untuk memacu peningkatan PAD Kabupaten Kuningan yang masih rendah. Tahun 2013, PAD Kabupaten Kuningan baru mencapai Rp 120 miliar sedangkan APBD Kabupaten Kuningan mencapai lebih dari 1,2 triliun. Ini artinya kontribusi PAD terhadap APBD masih sangat rendah. Oleh karena itu pihak DPRD mentargetkan kepada Bupati untuk terus meningkatkan $P A D$, dan pada tahun 2016, PAD Kabupaten Kuningan ditargetkan mencapai Rp 200 miliar. $^{10}$

Potensi yang bisa diandalkan oleh Kabupaten Kuningan dalam peningkatan PAD tentunya bersumber dari penerimaan pajak dan retribusi daerah. Oleh karena itu potensi inilah yang dicoba oleh Pemerintah Daerah untuk terus ditingkatkan. Upaya yang dilakukan tentunya dengan mempermudah pemberian ijin pembangunan yang perpotensi mendatangkan pajak yang besar. Satu diantaranya adalah dengan pemberian ijin-ijin pembangunan perumahan di kawasan Cilimus Selatan.

Sebagai norma hukum, Peraturan Daerah Nomor 26 Tahun 2011 sudah dilengkapi dengan perangkat sansi-sanksi baik administrasi, pidana maupun perdata. Namun kenyataannya pelanggaran alih fungsi lahan tersebut tetap terjadi tanpa ada upaya pengenaan sanksi bagi para pelanggarnya. tidak efektifnya pengawasan Badan Koordinasi Penataan Ruang Daerah (BKPRD) yang dipimpin oleh Sekertaris Daerah sebagai lembaga yang dibentuk untuk pengawasan dan evaluasi pelaksanaan Tata Ruang menjadi salah satu faktor terjadinya penyimpangan terhadap perencanaa tata ruang

\footnotetext{
${ }^{10}$ Simpulandarihasil WawancaradenganKepalaDinasPendapata n Daerah KabupatenKuningan, padatanggal 18 Juni 2015
}

di Pusat Kegiatan Lokal Cilimus. Padahal BKPRD adalah badan yang bersifat adhoc yang dibentuk untuk mendukung pelaksanaan Undang Undang Nomor 26 Tahun 2007 dan Peraturan Daerah Nomor 26 Tahun 2011. Ketidakkonsistenan Pemerintah Daerah Kabupaten Kuningan dalam penerapan kebijakan tata ruang disebabkan juga karena tidak dirumuskannya Rencana Detail Tata Ruang (RDTR) Cilimus dalam suatu Peraturan Daerah sehingga tidak memiliki legalitas. Menurut Thomas R Dye, ${ }^{11}$ kebijakan tidak dapat menjadi kebijakan publik kalau tidak dirumuskan, disahkan dan dilaksanakan oleh lembaga pemerintah. Riant Nugroho menggambarkan bagaimana kebijakan yang dibuat dapat dilaksanakan atau tidak bergantung pada sumber daya yang tersedia serta memperhatikan prinsip-prinsip good government yaitu transparansi, akuntabilitas, adil, dan bertanggung jawab. ${ }^{12}$

Pemanfaatan ruang untuk mengembangkan dan mengalokasikan kegiatan serta tempat pemukiman penduduk seharusnya tidak boleh melanggar ketentuan Rencana Detail Tata Ruang Cilimus, apalagi kalau memperhatikan kebijakan untuk mempertahankan lahan pertanian terutama sawah beririgasi teknis sebagai Ruang Terbuka Hijau (RTH) seperti tercantum dalam Peraturan Menteri Dalam Negeri Nomor 1 Tahun 2007 tentang Penataan Ruang Terbuka Hijau Kawasan Perkotaan, maka kawasan perkotaan Kecamatan Cilimus sebagai pusat pengembangan pariwisata Kabupaten Kuningan seharusnya dominan dengan Ruang Terbuka Hijau sehingga akan bersinergi dengan pengembangan fungsi perkotaan sebagai penunjang pariwisata. Begitu pula kalau kita mengacu kepada Undang Undang Nomor 41 Tahun 2009, yang menjelaskan bahwa lahan pertanian memiliki peran dan fungsi strategis karena sebagian besar penduduk di Indonesia menggantungkan hidup pada sektor pertanian.

Pemerintah Daerah dalam implementasi kebijakan seharusnya memiliki komitmen dengan

\footnotetext{
${ }^{11}$ RiantNugroho, Op.Cithlm 164

${ }^{12}$ Ibid, hlm 164
} 
apa yang dituangkan dalam rencana tata ruang, karena seperti yang dikatakan oleh Andersen bahwa kebijakan publik adalah kebijakan yang dikembangkan oleh badan-badan dan pejabat pemerintah. Adapun tujuan penting dari kebijakan itu adalah memelihara ketertiban umum, melancarkan perkembangan masyarakat dalam berbagai hal aktifitas dan peruntukannya dan membagi berbagai materi atau pengalokasiannya. ${ }^{13}$

Kepastian penataan ruang merupakan permasalahan di daerah, kebijakan ini mendesak dilaksanakan sebab banyak permasalahan di daerah yang bersumber dari pelanggaran tata ruang.Secaraumum, penataan tata ruang di Jawa Barat belum optimal, bahkan cenderung inkonsisten yang menyebabkan terjadinya alih fungsi lahan. Hal ini juga disorot oleh Pemerintah Pusat melalui Kementerian Agraria dan Tata Ruang ${ }^{14}$ yang melihat belum ada keselarasan dalam penataan tata ruang dan wilayah di Jawa Barat, sehingga Pemerintah Pusat meminta agar Pemerintah Provinsi Jawa Barat dan seluruh Kabupaten/Kota di Jawa Barat untuk lebih cermat dalam menyusun rencana tata ruangnya. Untuk itu diperlukan komitmen dan kosistensi seluruh sektor pembangunan. Hal ini dimaksudkan untuk mewujudkan harmonisasi program pembangunan separsial dengan Rencana Pembangunan Jangka Menengah Daerah melalui sinkronisasi program pemanfaatan ruang dan instrumen pengendaliannya.Tujuan utama dari penataan ruang adalah bukan hanya dimaksudkan untuk mewujudkan suatu kota atau daerah di Indonesia tidak tumbuh semerawut dan tidak enak di pandang mata tetapi juga menghindari timbulnya kerusakan lingkungan dan bahaya ancaman bencana alam.

Terjadinya pelanggaran alih fungsi peruntukan di Kecamatan Cilimus, ${ }^{15}$ sangat disayangkan

\footnotetext{
${ }^{13}$ Tachjan, Op.Cit. hlm 15

${ }^{14}$ PernyataanMenteriAgrariadantataRuangFeryMursidanBald andalamBerita HU Pikiranrakyat, Sabtu 23 Mei 2015, hlm 24

${ }^{15}$ SimpulandarihasilwawancarapribadidenganSudarna

(61 tahun) Ketua BPD DesaLinggajatiCilimus, tanggal $15 \mathrm{Mei}$ 2015
}

dengan adanya alih fungsi lahan pertanian menjadi areal perumahan seperti yang terjadi di Desa Bandorasa Wetan. Visi Kuningan sebagai Kabupaten Konservasi dengan kegiatan agropolitan yang seharusnya menjadi program yang diunggulkan adalah cermin dari visi misi Kabupaten Kuningan sebagai daerah agraris yang mengandalkan sektor pertanian tapi malah tidak sesuai kenyataan. Pemerintah Daerah tidak berpihak pada program Kuningan sebagai Kabupaten Konservasi. Hal ini tidak lepas dari keinginan yang tinggi untuk meningkatkan PAD dan iming-iming memperoleh keuntungan pribadi seringkali mengakibatkan pihak Pemerintah Daerah mengeluarkan kebijakan yang tidak mencerminkan keberlangsungan lahan pertanian yang akan datang. Akan menjadi sangat kontradiktif bila ternyata sebuah aturan yang seharusnya menjadi pedoman dan arahan untuk mengatur tata ruang pada suatu wilayah malah menjadikan wilayah tersebut tidak tertata dan mengabaikan lingkungannya. ${ }^{16}$

Mencermati kondisi tersebut di atas, terlihat bahwa Pemerintah Daerah berada dalam situasi dilematis dalam menentukan kebijakan berkaitan dengan upaya untuk meningkatkan Pendapatan Asli Daerah (PAD), karena besarnya tekanan legislatif (DPRD) kepada eksekutif (Pemerintah Daerah) untuk terus memacu peningkatan Pendapatan Asli Daerah (PAD). Sehingga menimbulkan pertanyaan, model kebijakan publik seperti apa yang diterapkan pada persoalan peningkatan Pendapatan Asli Daerah yang selama ini hanya mengandalkan dari obyek pajak dan retribusi daerah saja. Berpijak pada karakter pengambilan kebijakan yang pada implementasinya tidak sensitif terhadap kepekaan sosial kiranya dapatlah kebijakan publik yang dilakukan oleh pemerintah daerah mengacu pada Model Elit Massa, ${ }^{17}$ merupakan

\footnotetext{
${ }^{16}$ SimpulandarihasilwawancarapribadidenganJumhari tahun) WargaCilimus yang juga Pegawai Badan Pengelolaan LingkunganHidup (BPLHD) KabupatenKuninganpadatanggal 16 Mei 2015

17 Wayne Parsons, Public Policy: Pengantar, TeoridanPraktekAnalisisKebijakan (dialihbahasakanoleh Tri
} 
model dimana kelompok kecil masyarakat adalah pemegang kekuasaan. Elit massa dianggap mengetahui tentang kebutuhan massa. Implikasi dari teori ini adalah para elit menerapkan kebijakan publik tidak sebagai refleksi atau merupakan tuntutan masyarakat tetapi implementasinya lebih banyak demi kepentingan elit itu sendiri. Dengan demikian definisi kebijakan publik merupakan hasil definisi dari para elit, dan para elit berpandangan bahwa massa atau masyarakat lebih banyak apatis dan sering dimanipulasi oleh elit.

\section{KESIMPULAN}

Berdasarkan pembahasan tersebut di atas maka dapat diambil kesimpulan sebagai berikut:

a. Pengaturan Hak Asasi Manusia di Indonesia, sudah diatur dalam Undang Undang Dasar 1945 dan tercantum pada Pasal 28 A s/d $28 \mathrm{~J}$. Pemunculan, perumusan dan institusionalisai Hak Asasi Manusia (HAM) memang tak dapat dilepaskan dari lingkungan sosial atau habitatnya, yaitu tidak lain masyarakat itu sendiri di mana HAM itu dikembangkan. Terjadi semacam korespondensi antara HAM dan perkembangan masyarakat. Kita juga dapat mengatakan, bahwa HAM itu memiliki watak sosial dan struktur sosial sendiri.

b. Kebijakan Daerah di bidang penataanruang telah terjadi inkonsistensi yaitu telah terjadi alih fungsi lahan pertanian menjadi perumahan terutama di kawasan Cilimus Selatan, yang arahan tataruangnya adalah untuk pengembangan sector pertanian dan dukungan terhadap pengembangan pariwisata, terjadi karena minimnya kesadaran masyarakat dalam menjaga lingkungan, rendahnya kesadaran hukum aparatur penyelenggara kebijakan, dan upaya pemerintah daerah untuk terus meningkatakan PAD tanpa melihat rencana tata ruang yang telah ditetapkan, telah menimbulkan berbagai pelanggaran alih

Wibowo Budi Santoso), (Jakrta, PT Kencana, 2008), hlm 143 fungsi lahan pertanian menjadi bangunan perumahan. Alih fungsi lahan pertanian merupakan ancaman terhadap pencapaian ketahan dan kedaulatan pangan, mengingat Kabupaten Kuningan adalah salah satu Kabupaten di Jawa Barat sebagai penghasil utama produksi pertanian. Implikasi dari pelanggaran tata ruang ini sebenarnya memiliki konsekuensi yuridis baik secara administrasi, pidana maupun perdata, sebagaimana telah diatur dalam Undang Undang Nomor 26 Tahun 2007 tentang Penataan Ruang maupun dalam Peraturan Daerah Nomor 26 Tahun 2011 tentang Rencana Tata Ruang Wilayah Kabupaten Kuningan 2011-2031. Namun sampai saat ini upaya penegakan hokum terhadap pelanggaran tata ruang ini belum dilakukan secara optimal sehingga pelanggaran alih fungsi lahan masih terus berlangsung yang secara nyata telah melanggar Hak asasi manusia di kabupaten Kuningan.

\section{REKOMENDASI}

Pengaturan tentang HAM sudah sangat jelas dalam Konstitusi dan Undang-Undang yang berlaku di Indonesia. Penerapan HAM di dalam semua aspek kehidupan khususnya Tata Ruang perlu dukungan dari semua pihak terutama pemerintah sendiri yang harus konsisten dalam menjalankan semua peraturan dan perlu adanya peningkatan kapasitas aparatur sipil negara sehingga dalam menjalankan roda pemerintahaan senantiasa patuh dan taat terhadap peraturan perundangan khususnya mengaenai tata ruang.

\section{DAFTAR PUSTAKA}

Bambang Giyanto, 2001, Hukum Administrasi Negara, Lembaga Administrasi Negara, Jakarta

Bernard L Tanya, Yoan N Simanjuntak, Markus Y Hage,2013,Teori Hukum, Genta Publishing, Yogyakarta

Budi Winarno, 2012, Kebijakan Publik, Teori, Proses dan Studi Kasus, CAPS, Yogyakarta 
Eman Suparman, 2013, Arbitrase Dan DilemaPenegakanKeadilan, PT FikahatiAneska, Jakarta

Endang Sutrisno, 2007, Bunga Rampai Hukum dan Globalisasi, Genta Press, Jogjakarta

Esmi Warassih, 2005, Pranata Hukum Sebuah Telaah Sosiologis, Badan Penerbit Universitas Diponegoro, Semarang

Hasbullah, Afif. Politik Hukum Ratifikasi Konvensi HAM di Indonesia. 2005. UNISDA: Lamongan.

Hiarieji, Eddy. Pengadilan atas Beberapa Kejahatan Serius terhadap HAM. 2010. Erlangga: Jakarta.

Hakiem, Luqman. Deklarasi Islam tentang HAM. Muzaffar, Candra, dkk. Human's Wrong. 2007. Pilar Media: Yogyakarta.

Muladi. Hak Asasi Manusia. 2009. Refika Aditama: Bandung 